\title{
Maternal restraint stress negatively influences growth capacity of preimplantation mouse embryos
}

\author{
Ján Burkuš, Štefan Čikoš, Dušan Fabian, Janka Kubandová, Soňa Czikková and Juraj \\ Koppel
}

Institute of Animal Physiology, Slovak Academy of Sciences, Šoltésovej 4, 04001 Košice, Slovak Republic

\begin{abstract}
In our study we investigated the effect of maternal restraint stress on preimplantation embryo development using a mouse model. We exposed hormonally stimulated (superovulated) and unstimulated (i.e. spontaneously ovulating) mouse females to restraint stress for 30 min three times a day during the preimplantation period. The stress exposure caused significant increase in blood plasma corticosterone concentration. Microscopical evaluation of embryos isolated from spontaneously ovulating females showed that maternal stress significantly increased the proportion of embryos with lower cell numbers ( $\leq 32$ cells) and decreased the proportion of embryos with higher cell numbers (65-96 cells and 97-128 cells). Moreover maternal restraint stress decreased the cell counts per embryo and per blastocyst. After an additional $24 \mathrm{~h}$ in vitro culture we did not find any difference in the embryo distribution or in the cell counts per embryo/blastocyst between embryos isolated from stressed and control mothers. The exposure to restraint stress did not affect the incidence of apoptosis in blastocysts isolated from spontaneously ovulated dams. In gonadotropin stimulated dams, the hormonal treatment itself notably changed embryo distribution (increasing the proportion of degenerated embryos) and increased the occurrence of apoptotic cells. Our results indicate that psychical stress exposure in very early pregnancy can significantly influence the developmental capacity of preimplantation embryos.
\end{abstract}

Key words: Maternal stress — Preimplantation embryo - Apoptosis

\section{Introduction}

Excessive exposure to stress factors can have significant impact on female reproductive capacity. Stress mobilizes adaptive behaviors and peripheral functions, and inhibits biologically costly behaviors and vegetative functions, such as reproduction, feeding, and growth. Two major response systems are activated by stress: the hypothalamus-pituitaryadrenal cortex (HPA) axis and the sympathoadrenal system (SAS, involving the sympathetic nervous system and the adrenal medulla), and both these response systems can mediate the effects of stress on the female reproductive system as well as on the developing embryo (reviewed in Chrousos et al. 1998; Lazinski et al. 2008).

Correspondence to: Ján Burkuš, Institute of Animal Physiology, Slovak Academy of Sciences, Šoltésovej 4, 04001 Košice, Slovak Republic

E-mail: burkus@saske.sk
There is much evidence about the association of maternal stress during pregnancy with preterm birth (Ruiz et al. 2003), low birth weight (reviewed in Rondó et al. 2007), increased risk of behavioral changes in offspring (Miyagawa et al. 2011), neuropsychiatric disorders (Koenig et al. 2002) or development of insulin resistance (Entringer et al. 2008). Moreover, some results indicate that stressful life events may also reduce the chances of a successful outcome following IVF (in vitro fertilisation), possibly through psychobiological mechanisms affecting medical end-points such as oocyte retrieval outcome (Ebbesen et al. 2009). Animal and human studies indicate that the vulnerability to prenatal stress changes during the gestational period. Generally, the early stages of pregnancy seem to be more vulnerable than later stages, but the result can depend on the species, type of stressor and measured outcome (rewieved in Hobel et al. 2003; Lazinski et al. 2008). The preimplantation and periimplantation period of development is considered to be one of the most sensitive phases in mammalian ontogeny (Ford 
and Youngs 1993; Wilcox et al. 1999; Humblot 2001), and several studies have demonstrated that unfavourable conditions acting during this period can have long-term negative consequences (Kwong et al. 2000, 2007; Khosla et al. 2001; Edwards and McMillen 2002). However, only limited data are available about the effect of maternal stress acting during the preimplantation period (Wiebold et al. 1986; Lee et al. 2008), and stress exposure (or stress hormone treatment) has been restricted to the period of follicular growth, oocyte maturation or ovulation in the majority of studies (Brandt et al. 2007; Van Merris et al. 2007; Zhang et al. 2011). In the present study we investigated how the effect of maternal restraint stress applied during the preimplantation period can influence the developmental capacities of preimplantation embryos.

\section{Materials and Methods}

\section{Animals}

Female mice (ICR strain, Velaz, Prague, Czech Republic; 33-38 days old) were maintained under standard conditions (temperature $22 \pm 2{ }^{\circ} \mathrm{C}$, humidity $65 \pm 5 \%, 12: 12$-h light-dark cycle with lights on at 05:00, free access to food and water), and housed at 10 animals per cage. Preimplantation embryos were recovered from hormonally superovulated and spontaneously ovulating female mice. Females underwent superovulation treatment by intraperitoneal injection of 5 IU of serum gonadotropin (Folligon, Intervet International Bv. Boxmeer, Holland), followed $46 \mathrm{~h}$ later by administration of 5 IU of human chorionic gonadotropin (hCG, Organon, Oss, Holland). Females were mated with males of the same strain overnight (mating was confirmed by identification of a vaginal plug at 8:00 next morning). Spontaneously ovulating female mice were mated with males during one or more nights (mating was confirmed by identification of a vaginal plug every morning at 8:00 and this time was designated $0 \mathrm{~h}$ post plug, day 1 of pregnancy). After the vaginal plug appearance, superovulated and spontaneously ovulating mice were divided into two groups, stressed and control.

All animal experiments were reviewed and approved by the Ethical Committee for animal experimentation of the Institute of Animal Physiology, approved by the State Veterinary and Food Administration of the Slovak Republic, and were performed in accordance with Slovakian legislation based on EC Directive 86/609/EEC on the protection of animals used for experimental and other scientific purposes.

\section{Restraint stress}

Dams in the stressed group were subjected to restraint stress by being placed individually into adjusted and perforated
$50 \mathrm{ml}$ plastic tubes (without squeezing or compression). Each animal was isolated in a cell made of cardboard located outside of the animal colony during the stress exposure. Restraint stress was applied three times a day (at 8:00, 12:00, 16:00) for 30 min during the light phase of the day from day 1 to day 4 of pregnancy (D1-D4). After the stress exposure mice were returned to their home cage with free access to food and water. The body weights of stressed and control mice were measured every day between 8:30 and 9:00.

\section{Corticosterone measurement}

Females exposed to single $30 \mathrm{~min}$ restraint stress and control females were decapitated for blood collection. Blood samples were collected into tubes containing EDTA-2Na and centrifuged $\left(2000 \times g, 4^{\circ} \mathrm{C}, 15 \mathrm{~min}\right)$ to obtain blood plasma. The blood plasma was stored at $-80^{\circ} \mathrm{C}$ until the measurement of corticosterone concentrations. Corticosterone was measured using a commercially available EIA kit, according to the manufacturer's instructions (Corticosterone EIA kit, Enzo Life Sciences).

\section{Embryo recovery and embryo culture}

Dams from both the stress and the control group were killed by cervical dislocation on $\mathrm{D} 4$. This period, preceding the start of implantation, was chosen to avoid embryo loss (at D5 expanded hatched blastocysts start to implant in the endometrium, and at this stage they cannot be flushed from the uterus effectively). Embryos were recovered by flushing the oviduct and the uterus using a flushing-holding medium (FHM) (Lawitts and Biggers 1993) containing 1\% bovine serum albumin ((BSA, Sigma-Aldrich, St. Louis, USA).

Embryos developed in superovulated females were isolated $76 \mathrm{~h}$ post vaginal plug (SU-76h group/experiment: 30 stressed dams; 28 control dams). To cover a broader time period, embryos developed in spontaneously ovulating females were isolated $76 \mathrm{~h}$ post vaginal plug (SP-76h group/experiment: 22 stressed dams; 17 control dams) as well as $80 \mathrm{~h}$ post vaginal plug (SP-80h group/experiment: 21 stressed dams; 23 control dams). The two isolation times used in spontaneously ovulating females enabled us to obtain experimental material which probably compares better with that obtained from superovulated females.

For the in vitro experiment, embryos developing in spontaneously ovulating females were isolated $76 \mathrm{~h}$ post vaginal plug, and further cultured (SP-24h cult group/experiment: 19 stressed dams; 17 control dams). Isolated embryos were washed in KSOM culture medium (Specialty Media Group, Phillipsburg, NJ, USA), transferred to KSOM culture drops ( 1 embryo/1 $\mu \mathrm{KSOM}$ ), covered with mineral oil and cultured under standard conditions $\left(5 \% \mathrm{CO}_{2}\right.$ and $\left.37^{\circ} \mathrm{C}\right)$ for $24 \mathrm{~h}$. 


\section{Evaluation of embryos}

The quality and the developmental capacity of freshly isolated embryos were assessed using morphological fluorescence staining. Immediately after isolation, embryos were first washed in phosphate-buffered saline (PBS) containing BSA, fixed in 4\% paraformaldehyde (Merck, Darmstadt, Germany) in PBS at room temperature for $1 \mathrm{~h}$ and stored in $1 \%$ paraformaldehyde in $\mathrm{PBS}$ at $4^{\circ} \mathrm{C}$. Fixed embryos were washed, permeabilized for $1 \mathrm{~h}$ in PBS with $0.5 \%$ Triton X-100 (Sigma-Aldrich) and again washed in PBS. Then they were incubated in TUNEL assay reagents (TUNEL, In Situ Cell Death Detection Kit; Roche, Penzberg, Germany) for $1 \mathrm{~h}$ at $37^{\circ} \mathrm{C}$ in the dark. After the TUNEL reaction, all embryos were counterstained with Hoechst 33342 (bisbenzimide $20 \mu \mathrm{g} / \mathrm{ml}$ in PBS; Sigma-Aldrich; stains all nuclei, shows nuclear morphology) for $5 \mathrm{~min}$ at room temperature, washed, mounted on a slide with Vectashield (Vector laboratories, Burlingame, CA, USA) and observed under fluorescence microscope at 400× magnification (BX50 Olympus, Japan).

The number of cell nuclei was determined in each embryo. For the analysis of embryo distribution, each embryo was assigned to one of five classes (cell numbers: $\leq 32$ cells, 33-64 cells, 65-96 cells, 97-128 cells, >128 cells) depending on its developmental stage. Degenerated embryos, unfertilized and fertilized oocytes, 2-16-cell embryos and morulas were assigned to the $\leq 32$ class, embryos with more than 32 cells were considered as blastocysts and assigned to one of the higher classes depending on the cell number.

According to the nuclear morphology and the presence of specific DNA fragmentation in the nucleoplasm, embryonic cells were classified as: normal (without morphological changes in nuclei, without TUNEL labeling in the nucleoplasm) or apoptotic (showing at least one of following features: fragmented or condensed nucleus, positive TUNEL labeling).

\section{Statistics}

Statistical analysis was performed using GraphPad Prism software (GraphPad Software, Inc., La Jolla, CA, USA). Student's $t$-test was used to detect differences in body weights of dams between control and stress groups, and the difference in corticosterone concentration in blood plasma. The MannWhitney test was used to detect differences in cell counts of embryos/blastocysts between control and experimental groups. The standard $\chi^{2}$ test was used for analysis of embryo distribution and apoptosis incidence (the square was created from the total number of normal and apoptotic cells in each experiment). Differences of $p<0.05$ were considered significant.

\section{Results}

Control dams gained, whereas stressed dams lost body weight during the period of the restraint stress application. At the day of embryo isolation (D4), the body weight of the stressed females was significantly lower than that of controls (Fig. 1). Blood plasma corticosterone concentration was significantly higher in the females exposed to restraint stress than in the control females (Fig. 2).

Table 1 shows that restraint stress changed the distribution of freshly isolated embryos according to embryo cell number in three experiments (SU-76h, SP-76h and SP-80h). We found no statistically significant difference in the distribution of embryos between the stressed and the control group after additional $24 \mathrm{~h}$ culture in vitro. In the SP-76h experiment the percentage of degenerated/low cell number embryos ( $\leq 32$ cells) was increased and the percentage of early (33-64 cells), medium (65-96 cells) and expanded blastocysts (97-128 cells) was decreased in the stressed group compared to control. Similarly, in the SP-80h experiment the proportion of degenerated/low cell number embryos ( $\leq 32$ cells) and early blastocysts (33-64 cells) was increased and the proportion of medium blastocysts (65-96 cells) and expanded blastocysts (97-128 cells) was decreased in the stress group compared to the corresponding control group. Surprisingly, in the SU-76h experiment, there was a lower proportion of degenerated/low cell number embryos ( $\leq 32$ cells) in the stress group compared to control. Furthermore, the proportion of early blastocysts (33-64 cells) was elevated, whereas the proportion of medium blastocysts (65-96 cells) and expanded blastocysts (97-128 cells) was decreased in the stress group compared to control. In both control and stress groups, the proportion of degenerated embryos isolated from superovulated females was notably higher than the proportion of degenerated embryos isolated from spontaneously ovulating females (SU-76h: 14.5\% in control and $7.9 \%$ in stressed group; SP-76h: $1.2 \%$ in control and $5.5 \%$ in stressed group; SP-80h: $1.6 \%$ in control and $1.6 \%$ in stressed group).

Embryos isolated from stressed mothers had significantly lower cell number compared to corresponding control embryos in the SP-76h and SP-80h experiments; no statistically significant difference was found in the SU-76h experiment (Fig. 3). On the other hand, the cell counts of blastocysts isolated from stressed dams was significantly lower in all three experiments (SU-76h, SP-76h, SP-80h). Embryos/blastocysts cultured for $24 \mathrm{~h}$ after their isolation from stressed or control mothers showed no significant size differences.

No statistically significant difference in the incidence of apoptosis was found between blastocysts isolated from stressed and control mothers in the experiments using spontaneously ovulating females (SP-76h, SP-80h, SP $24 \mathrm{~h}$ 


\section{Discussion}

Animal restraint is used as a standard procedure that induces psychogenic stress in individuals and mimics psychosocial stress and depression in humans (Paré and Glavin 1986; Glavin et al. 1994). In our experiment we applied short restraint (30 $\mathrm{min}$ ) three times a day to avoid adaptation (ha- bituation) of mice to stress conditions. To validate our stress model, we measured corticosterone (the main glucocorticoid involved in regulation of stress responses in rodents, Thaete et al. 1990) in blood plasma, and found about twelve times higher concentration of this hormone in the females exposed to restraint stress. Significant loss of body weight in the stressed females further proved the validity of our stress model.
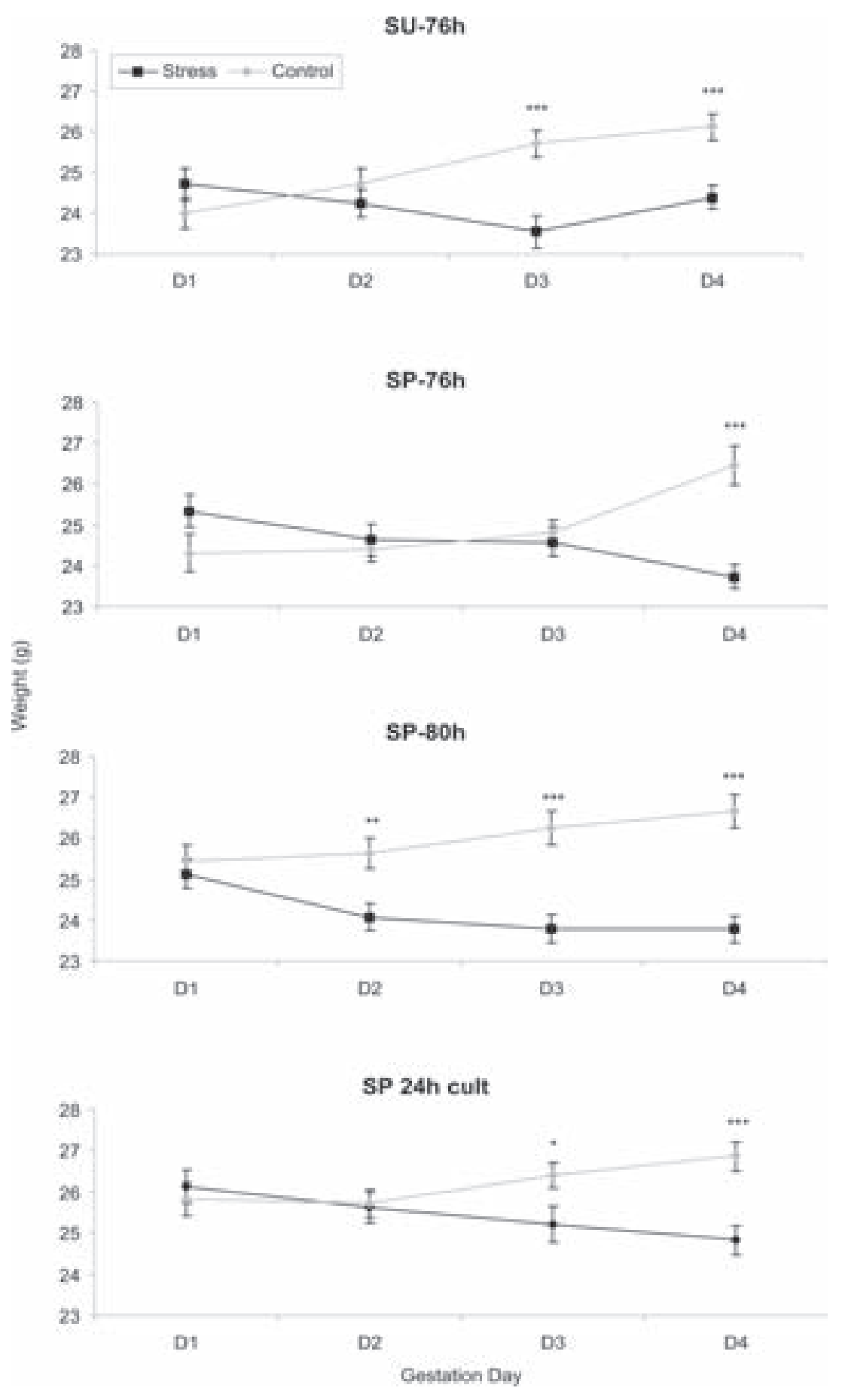

Figure 1. Body weights of dams after exposure to restraint stress during the preimplantation period. Black lines represent stressed dams; grey lines represent corresponding control dams. Values are arithmetical means \pm SEM. Statistical differences between stress groups and corresponding control groups were determined using Student's $t$-test, ${ }^{*} p<0.05 ;{ }^{* *} p<0.01 ;{ }^{* * *} p<$ 0.001. SU-76h, superovulated females, embryos isolated $76 \mathrm{~h}$ post vaginal plug; SP-76h, spontaneously ovulating females, embryos isolated $76 \mathrm{~h}$ post vaginal plug; SP-80h, spontaneously ovulating females, embryos isolated $80 \mathrm{~h}$ post vaginal plug; SP $24 \mathrm{~h}$ cult., spontaneously ovulating females, embryos isolated $76 \mathrm{~h}$ post vaginal plug and additional $24 \mathrm{~h}$ in vitro culture of embryos. 


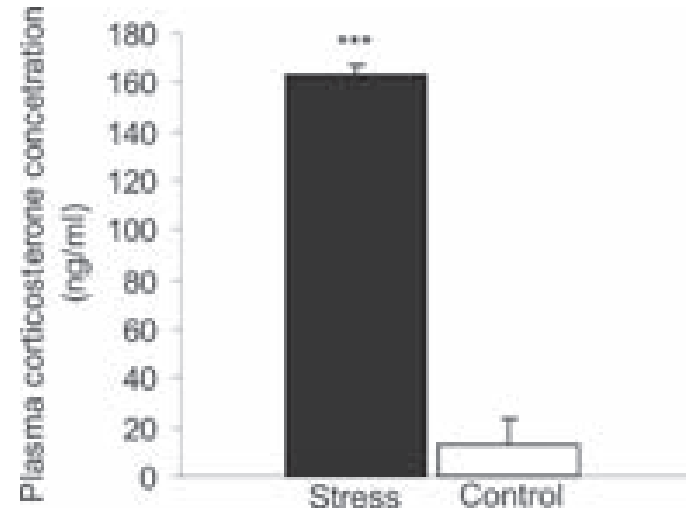

Figure 2. Blood plasma corticosterone concentrations after exposure to restraint stress. The black column represents stressed dams and the white column represents corresponding control dams. Values are arithmetical means \pm SEM. Statistical difference between stressed and control females was assessed using Student's $t$-test, ${ }^{* * *} p<0.001$.

The restraint stress applied to mouse females during the preimplantation period had adverse effect on embryo development in our experiments. We found significant change in the distribution of freshly isolated embryos according to embryo cell number in the two experiments where spontaneously ovulating female mice were used. The restraint stress increased the proportion of degenerated and slowly developing embryos and decreased the proportion of embryos with higher cell numbers compared to the control groups. Consequently, the cell number (estimated in all embryos and in the fraction of embryos that reached the blastocyst stage) was reduced in embryos isolated from the stressed females. In contrast, the proportion of degenerated and slowly developing embryos was decreased in the stress group compared to control in the experiment using gonadotropin-stimulated females. Since superovulation led to increased occurrence of degenerated embryos in both control and stress groups, we assume that the hormonal treatment could contribute to the contradictory result in the embryo distribution (e.g. by modifying the embryo responsiveness to stress mediators). It is well known that superovulation increases the number of released oocytes at the expense of their quality, causing delayed embryonic development and increased formation of abnormal blastocysts (Chrenek et al. 1998; Van der Auwera and D'Hooghe 2001). On the other hand, separate evaluation of the embryos that reached the blastocyst stage showed similar results in both superovulated and spontaneously ovulating females in our experiment (decreased proportion of medium and expanded blastocysts, and decreased cell number in blastocysts developed in the stressed females). These results suggest that the fraction of oocytes whose quality is probably less influenced by the superovulation hormone treatment can develop into embryos which behave similarly to embryos from spontaneously ovulating females.

Table 1. Embryo distribution after exposure to maternal restraint stress during the preimplantation period (in \%)

\begin{tabular}{|c|c|c|c|c|c|c|c|c|}
\hline \multirow[b]{2}{*}{ Group } & & \multicolumn{5}{|c|}{ Developmental stage of embryo } & \multirow[b]{2}{*}{$n$} & \multirow[b]{2}{*}{$p$} \\
\hline & & $\begin{array}{l}\text { Degenerated/low } \\
\text { cell number } \\
\text { embryos } \\
(\leq 32 \text { cells })\end{array}$ & $\begin{array}{c}\text { Early } \\
\text { blastocysts } \\
\text { (33-64 cells) }\end{array}$ & $\begin{array}{c}\text { Medium } \\
\text { blastocysts } \\
\text { (65-96 cells) }\end{array}$ & $\begin{array}{c}\text { Expanded } \\
\text { blastocysts } \\
(97-128 \text { cells })\end{array}$ & $\begin{array}{c}\text { Late } \\
\text { blastocysts } \\
(>128 \text { cells })\end{array}$ & & \\
\hline \multirow{2}{*}{ SU-76h } & $\mathrm{C}$ & 37.2 & 34.2 & 26.0 & 2.6 & - & 531 & \multirow{2}{*}{$* * *$} \\
\hline & $\mathrm{S}$ & 25.8 & 49.4 & 23.9 & 0.9 & - & 454 & \\
\hline \multirow{2}{*}{ SP-76h } & $\mathrm{C}$ & 26.2 & 61.0 & 12.2 & 0.6 & - & 274 & \multirow{2}{*}{$* * *$} \\
\hline & $\mathrm{S}$ & 48.5 & 48.9 & 2.6 & - & - & 164 & \\
\hline \multirow{2}{*}{ SP-80h } & $\mathrm{C}$ & 6.1 & 38.8 & 49.0 & 6.1 & - & 252 & \multirow{2}{*}{$* * *$} \\
\hline & $\mathrm{S}$ & 11.1 & 59.1 & 29.4 & 0.4 & - & 247 & \\
\hline \multirow{2}{*}{$\begin{array}{l}\text { SP } 24 \mathrm{~h} \\
\text { cult. }\end{array}$} & $\mathrm{C}$ & 1.1 & 3.5 & 24.9 & 65.9 & 4.6 & 241 & \multirow{2}{*}{ NS } \\
\hline & S & 1.7 & 1.7 & 29.0 & 64.7 & 2.9 & 173 & \\
\hline
\end{tabular}

After isolation embryos were stained (Hoechst 33342, TUNEL assay) and the cell number in each embryo was determined. Each embryo was assigned to one of five classes according to the cell number. The number of embryos from each experimental group belonging in the indicated developmental classes is expressed as a percentage. SU-76h, superovulated females, embryos isolated $76 \mathrm{~h}$ post vaginal plug; SP-76h, spontaneously ovulating females, embryos isolated $76 \mathrm{~h}$ post vaginal plug; SP-80h, spontaneously ovulating females, embryos isolated $80 \mathrm{~h}$ post vaginal plug; SP $24 \mathrm{~h}$ cult., spontaneously ovulating females, embryos isolated $76 \mathrm{~h}$ post vaginal plug and additional $24 \mathrm{~h}$ in vitro culture of embryos; C, embryos isolated from control dams; S, embryos isolated from stressed dams; $n$, number of embryos. Statistical difference between stress groups and corresponding control groups was assessed using $\chi^{2}$ test: NS, statistically non-significant difference; ${ }^{* *} p<0.001$. 


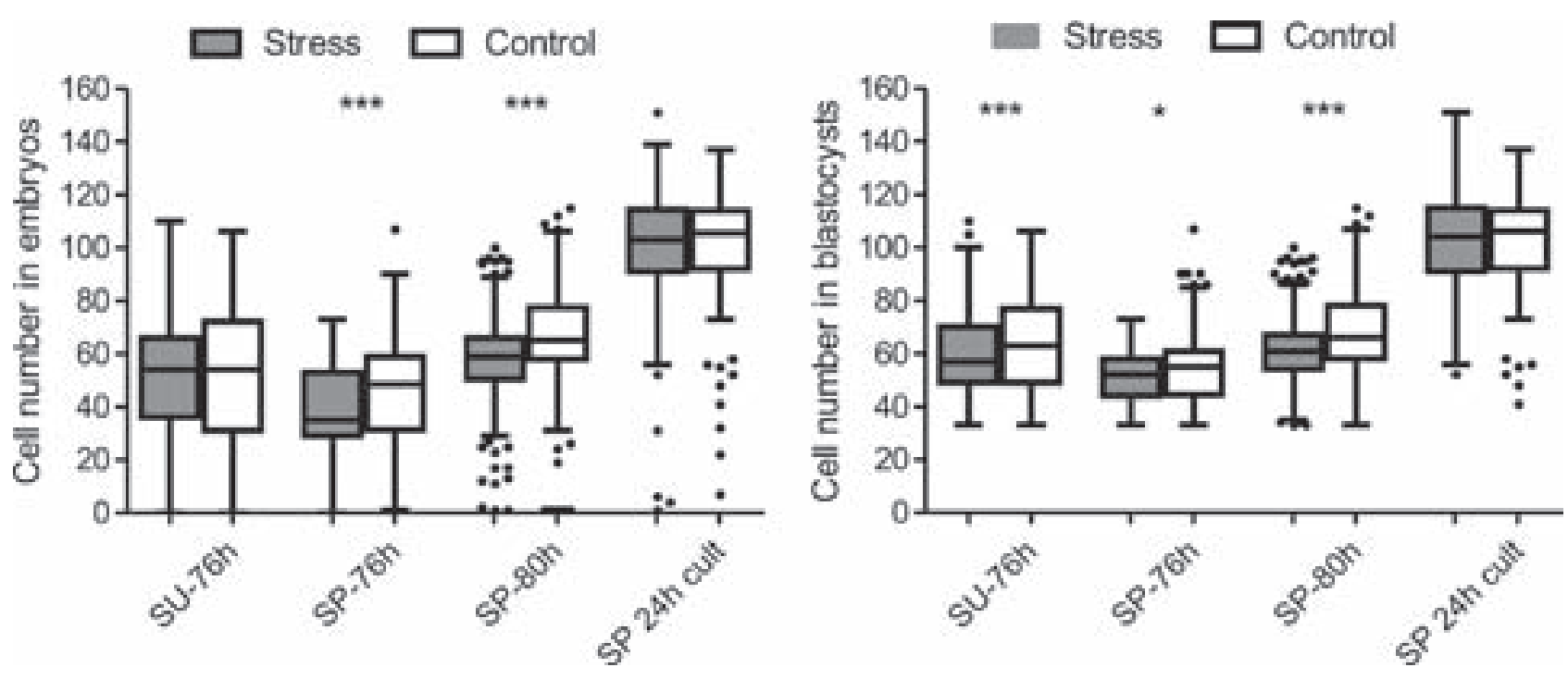

Figure 3. The cell counts in embryos/blastocysts after exposure to maternal restraint stress during the preimplantation period. The boxes represent the 25th to 75th percentiles, and horizontal lines within the box represent median values. The whiskers represent the lowest and highest value in the 25th percentile minus 1.5IQR (interquartile range) and 75th percentile plus $1.5 \mathrm{IQR}$ regions, respectively. Statistical difference between stressed groups and corresponding control groups was assessed using the Mann Whitney test: ${ }^{*} p<0.05$; ${ }^{* * *} p<0.001$. Total number of evaluated embryos/blastocysts in the experimental groups: SU-76h: Stress 489/394, Control 387/284; SP-76h: Stress 257/236, Control 164/149; SP-80h: Stress 245/223, Control 241/232; SP 24h cult: Stress 241/237, Control 174/171. For abbreviations see Fig. 1.

To ascertain if stressed embryos are able to reach the stage of expanded blastocyst prepared to implant, we cultured embryos isolated from spontaneously ovulating dams for an additional $24 \mathrm{~h}$ in vitro. Surprisingly, the stressed embryos finished their development at similar stages as the control embryos. This result suggests that the growth retardation caused by maternal restraint stress during the preimplantation period might be remedied after the stress removal, and the embryos are probably able to survive and develop further without substantial damage. Alternatively, the in vitro stress of the culture environment could override the differences in growth capacity between embryos isolated from normal and stressed mothers.

Results from animal experiments indicate that negative environmental factors (e.g. maternal malnutrition or in $v i$ tro culture) acting during the preimplantation developmental period can not only influence the early embryo, but also have long-term consequences reaching even into adult life (Kwong et al. 2000, 2007; Khosla et al. 2001; Edwards and McMillen 2002). In accord with these data, Lee et al. (2008) found decreased fetal body weight and increased resorption and fetal skeletal abnormalities after the exposure of mice females to restraint stress during the preimplantation period. Another study demonstrated that restraint stress applied during the preimplantation period can reduce the pregnancy rate and average litter size in mice (Wiebold et al. 1986). The effects found in these studies reflect the change in embryo developmental competence induced by maternal restraint stress at the very early pregnancy stage, and similarly our results clearly demonstrate the impaired developmental capacity of the early embryos. In addition, there are data indicating that maternal restraint stress can influence ovulation and oocyte developmental potential.

Table 2. Incidence of apoptosis in blastocysts after exposure to maternal restraint stress during the preimplantation period (in \%)

\begin{tabular}{llccrl}
\hline Group & & $\begin{array}{r}\text { Normal } \\
\text { cells (\%) }\end{array}$ & $\begin{array}{c}\text { Apoptotic } \\
\text { cells (\%) }\end{array}$ & \multicolumn{1}{c}{$n$} & $p$ \\
\hline \multirow{2}{*}{ SU-76h } & C & 97.56 & 2.44 & 18166 & \multirow{2}{*}{$* *$} \\
& S & 97.98 & 2.02 & 23365 & \\
\cline { 2 - 6 } SP-76h & C & 98.97 & 1.03 & 6589 & \multirow{2}{*}{ NS } \\
& S & 99.02 & 0.98 & 7227 & \\
\cline { 2 - 6 } SP-80h & C & 98.71 & 1.29 & 15994 & \multirow{2}{*}{ NS } \\
SP 24h & C & 98.74 & 1.26 & 13692 & \\
nult. & S & 98.80 & 1.20 & 17636 & \multirow{2}{*}{ NS } \\
\hline
\end{tabular}

Blastocysts were evaluated using fluorescence staining (Hoechst, TUNEL). The number of normal and apoptotic cells from each experimental group is expressed as a percentage (criteria for normal and apoptotic cells are described in Materials and Methods). Statistical difference between stressed groups and corresponding control groups was assessed using $\chi^{2}$ test: NS, statistically non-significant difference; ${ }^{* *} p<0.01$. For abbreviations see Table 1 . 
The negative effect of restraint stress on the number of ovulated oocytes has been shown in rats (Donadio et al. 2007). Zhang et al. (2011) proved that changes caused by restraint stress during follicular growth and oocyte maturation (in both unstimulated and hormonally stimulated mice) can negatively influence in vivo and in vitro embryo development.

Several studies have demonstrated that the exposure of an organism to restraint/immobilization stress (or administration of various stress mediators) can have a significant influence on cell survival and apoptosis (Sasagawa et al. 2001; Sastry et al. 2007; Engelbrecht et al. 2010). In our study we did not find significant effect of restraint stress on the incidence of apoptosis in blastocysts isolated from spontaneously ovulating mice. On the other hand, we found significant decrease in the proportion of apoptotic cells in the stress group compared to the control group in blastocysts isolated from superovulated mice. Since the superovulation treatment itself caused about two-fold increase in the incidence of apoptosis, the difference in the incidence of apoptosis found between embryos from the stressed and control females probably did not reflect the effect of stress exposure, and may have resulted from the influence of superovulation on the quality of preimplantation embryos. Thus our results do not provide evidence for the role of apoptosis in the response of early embryos to maternal stress, and further investigations are needed to make a conclusion.

The mechanisms by which stress impairs early embryo development are largely unknown, and the involvement of two major stress response systems is considered: the HPA axis (CRH (corticotropin-releasing hormone) - ACTH (adrenocorticotropic hormone) - glucocorticoids) and the sympathoadrenal system (catecholamines released from sympathetic nerve terminals and from adrenal medulla). The inhibitory effect of the HPA axis (when activated by stress) on the female reproductive system is well known, and involves suppression of the hypothalamic-pituitary-ovarian (HPO) axis (GnRH - gonadotropins - ovarian steroids) at the hypothalamic, pituitary, ovarian and uterine levels (Calogero et al. 1996; Chrousos et al. 1998; Tetsuka et al. 1999). Moreover, several animal studies have demonstrated the negative consequences of embryo overexposure to glucocorticoids originating from endogenous overproduction with maternal stress or from exogenous administration. On the other hand, it is necessary to note that the influences of glucocorticoids on embryo development are balanced between positive effects that promote pregnancy versus negative effects that can compromise the pregnancy (reviewed in Drake et al. 2007; Michael and Papageorghiou 2008). Only a few animal experiments have examined the effects of glucocorticoids on embryos at the preimplantation developmental stage. Van Merris et al. (2007) found decreased rates of mouse blastocyst formation after in vitro culture in the presence of dexamethasone. Zhang et al. (2011) showed that administration of cortisol to female mice during oocyte maturation can result in decreased rates of blastocyst formation and lower cell number per blastocyst in embryos obtained after in vitro fertilization. Another study found lower retrieval rate of oocytes/preimplantation embryos in ACTH-treated sows (Brandt et al. 2007). Some observations in humans confirm the findings obtained in animal experiments. Pregnancies characterized by increased maternal cortisol during the first three weeks after conception are more likely to result in spontaneous abortion (Nepomnaschy et al. 2006). Antenatal administration of glucocorticoids to women in the first trimester increased the incidence of miscarriages and preterm births (Gur et al. 2004). Recently Siemieniuch et al. (2010) detected mRNA for the glucocorticoid receptor in bovine preimplantation embryos from the two-cell to blastocyst stage, which indicates that glucocorticoids could directly influence preimplantation embryos through binding to the glucocorticoid receptor. In addition, finding adrenergic receptors in mouse preimplantation embryos (Čikoš et al. $2005,2007)$ suggests that catecholamines released in stress conditions from maternal sympathetic nerve terminals and the adrenal medulla could directly influence preimplantation embryo as well. The treatment of mouse preimplantation embryos in vitro with $\beta$-adrenergic or a 2 -adrenergic agonists significantly reduced the proportion of embryos which reached higher developmental stages, and the mean embryo cell number was significantly lower (Čikoš et al. 2005, 2007). In rats, elevated maternal noradrenalin and serotonin levels led to increased occurrence of degenerated or low developmental-stage embryos (Mihalik et al. 2008, 2010). However, besides glucocorticoids and catecholamines, other stress mediators are released in the stress response, so more investigation is necessary to understand molecular mechanisms which mediate the influences of maternal stress on early embryo development.

In summary, our results show that maternal restraint stress can directly influence the developmental capacity of the preimplantation embryo. These results support the opinion that psychical stress is one of the factors which can negatively influence the ability to conceive. Thus the impact of exposure to psychical stress during very early pregnancy should not be underestimated and should be regarded as a potential risk factor in human reproduction.

Author contributions: J.B.: acquisition, analysis and interpretation of data, writing the article. Š.Č.: conception and design of the study, data analysis and interpretation, critical reading of the manuscript. D.F.: experimental design, data analysis and interpretation, critical reading of the manuscript. J.Ku. and S.C.: embryo recovery and analysis of blood samples. S.C.: embryo recovery and analysis of blood samples. J.Ko.: experimental design, interpretation of data, critical reading of the manuscript. All authors have read and approved the final manuscript. 
Acknowledgements. This work was supported by the Slovak Academy of Sciences under contracts VEGA 2/0041/09 and VEGA 2/0029/12. We thank Dana Čigašová for her technical assistance and Andrew Billingham for his English proof-reading.

\section{References}

Brandt Y., Madej A., Rodríguez-Martínez H., Einarsson S. (2007) Effects of exogenous ACTH during oestrus on early embryo development and oviductal transport in the sow. Reprod. Domest. Anim. 42, 118-125 http://dx.doi.org/10.1111/j.1439-0531.2006.00698.x

Calogero A. E., Burrello N., Negri-Cesi P., Papale L., Palumbo M. A., Cianci A., Sanfilippo S., D’Agata R. (1996): Effects of corticotropin-releasing hormone on ovarian estrogen production in vitro. Endocrinology 137, 4161-4166 http://dx.doi.org/10.1210/en.137.10.4161

Chrenek P., Makarevich A., Vasícek D., Laurincík J., Bulla J., Gajarská T., Rafay J. (1998): Effects of superovulation, culture and microinjection on development of rabbit embryos in vitro. Theriogenology 50, 659-666 http://dx.doi.org/10.1016/S0093-691X(98)00170-8

Chrousos G. P., Torpy D. J., Gold P. W. (1998): Interactions between the hypothalamic-pituitary-adrenal axis and the female reproductive system: clinical implications. Ann. Intern. Med. 129, 229-240

Čikoš Š., Veselá J., Il'ková G., Rehák P., Czikková S., Koppel J. (2005): Expression of beta adrenergic receptors in mouse oocytes and preimplantation embryos. Mol. Reprod. Dev. 71, 145-153 http://dx.doi.org/10.1002/mrd.20256

Čikoš Š., Rehák P., Czikková S., Veselá J., Koppel J. (2007): Expression of adrenergic receptors in mouse preimplantation embryos and ovulated oocytes. Reproduction 133, 1139-1147 http://dx.doi.org/10.1530/REP-07-0006

Donadio M. V., Kunrath A., Corezola K. L., Franci C. R., AnselmoFranci J. A., Lucion A. B., Sanvitto G. L. (2007): Effects of acute stress on the day of proestrus on sexual behavior and ovulation in female rats: participation of the angiotensinergic system. Physiol. Behav. 92, 591-600 http://dx.doi.org/10.1016/j.physbeh.2007.05.005

Drake A. J., Tang J. I., Nyirenda M. J. (2007): Mechanisms underlying the role of glucocorticoids in the early life programming of adult disease. Clin. Sci. (Lond.) 113, 219-232 http://dx.doi.org/10.1042/CS20070107

Ebbesen S. M., Zachariae R., Mehlsen M. Y., Thomsen D., Højgaard A., Ottosen L., Petersen T., Ingerslev H. J. (2009): Stressful life events are associated with a poor in-vitro fertilization (IVF) outcome: a prospective study. Hum. Reprod. 24, 2173-2182 http://dx.doi.org/10.1093/humrep/dep185

Edwards L. J., McMillen I. C. (2002): Impact of maternal undernutrition during the periconceptional period, fetal number, and fetal sex on the development of the hypothalamo-pituitary adrenal axis in sheep during late gestation. Biol. Reprod. 66, 1562-1569 http://dx.doi.org/10.1095/biolreprod66.5.1562

Engelbrecht A. M., Smith C., Neethling I., Thomas M., Ellis B., Mattheyse M., Myburgh K. H. (2010): Daily brief restraint stress alters signaling pathways and induces atrophy and apoptosis in rat skeletal muscle. Stress 13, 132-141 http://dx.doi.org/10.3109/10253890903089834

Entringer S., Wüst S., Kumsta R., Layes I. M., Nelson E. L., Hellhammer D. H., Wadhwa P. D. (2008): Prenatal psychosocial stress exposure is associated with insulin resistance in young adults. Am. J. Obstet. Gynecol. 199, 498.e1-7

Ford S. P., Youngs C. R. (1993): Early embryonic development in prolific Meishan pigs. J. Reprod. Fertil. Suppl. 48, 271-278

Glavin G. B., Paré W. P., Sandbak T., Bakke H. K., Murison R. (1994): Restraint stress in biomedical research: an update. Neurosci. Biobehav. Rev. 18, 223-249 http://dx.doi.org/10.1016/0149-7634(94)90027-2

Gur C., Diav-Citrin O., Shechtman S., Arnon J., Ornoy A. (2004): Pregnancy outcome after first trimester exposure to corticosteroids: a prospective controlled study. Reprod. Toxicol. 18, 93-101 http://dx.doi.org/10.1016/j.reprotox.2003.10.007

Hobel C., Culhane J. (2003): Role of psychosocial and nutritional stress on poor pregnancy outcome. J. Nutr. 133, S1709-1717

Humblot P. (2001): Use of pregnancy specific proteins and progesterone assays to monitor pregnancy and determine the timing, frequencies and sources of embryonic mortality in ruminants. Theriogenology 56, 1417-1433 http://dx.doi.org/10.1016/S0093-691X(01)00644-6

Khosla S., Dean W., Reik W., Feil R. (2001): Culture of preimplantation embryos and its long-term effects on gene expression and phenotype. Hum. Reprod. Update 7, 419-427 http://dx.doi.org/10.1093/humupd/7.4.419

Koenig J. I., Kirkpatrick B., Lee P. (2002): Glucocorticoid hormones and early brain development in schizophrenia. Neuropsychopharmacology 27, 309-318 http://dx.doi.org/10.1016/S0893-133X(01)00396-7

Kwong W. Y., Wild A. E., Roberts P., Willis A. C., Fleming T. P. (2000): Maternal undernutrition during the preimplantation period of rat development causes blastocyst abnormalities and programming of postnatal hypertension. Development 127, 4195-4202

Kwong W. Y., Miller D. J., Wilkins A. P., Dear M. S., Wright J. N., Osmond C., Zhang J., Fleming T. P. (2007): Maternal low protein diet restricted to the preimplantation period induces a genderspecific change on hepatic gene expression in rat fetuses. Mol. Reprod. Dev. 74, 48-56 http://dx.doi.org/10.1002/mrd.20606

Lawitts J. A., Biggers J. D. (1993): Culture of preimplantation embryos. Methods Enzymol. 225, 153-164 http://dx.doi.org/10.1016/0076-6879(93)25012-Q

Lazinski M. J., Shea A. K., Steiner M. (2008): Effects of maternal prenatal stress on offspring development: a commentary. Arch. Womens Ment. Health 11, 363-375 http://dx.doi.org/10.1007/s00737-008-0035-4

Lee Y. E., Byun S. K., Shin S., Jang J. Y., Choi B. I., Park D., Jeon J. H., Nahm S. S., Kang J. K., Hwang S. Y. et al. (2008): Effect of maternal restraint stress on fetal development of ICR mice. Exp. Anim. 57, 19-25 http://dx.doi.org/10.1538/expanim.57.19

Michael A. E., Papageorghiou A. T. (2008): Potential significance of physiological and pharmacological glucocorticoids in early pregnancy. Hum. Reprod. Update 14, 497-517 
http://dx.doi.org/10.1093/humupd/dmn021

Mihalik J., Kravcuková P., Spakovská T., Mareková M., Schmidtová K. (2008): Study of high deprenyl dose on the preimlantation embryo development and lymphocyte DNA in rat. Gen. Physiol. Biophys. 27, 121-126

Mihalik J., Mašlanková J., Špakovská T., Mareková M., Hodorová I., Kušnír J., Rybárová S., Ferenc P., Schmidtová K. (2010): Impact of 2 doses of clorgyline on the rat preimplantation embryo development and the monoamine levels in urine. Reprod. Sci. 17, 734-741 http://dx.doi.org/10.1177/1933719110369181

Miyagawa K., Tsuji M., Fujimori K., Saito Y., Takeda H. (2011): Prenatal stress induces anxiety-like behavior together with the disruption of central serotonin neurons in mice. Neurosci. Res. 70, 111-117 http://dx.doi.org/10.1016/j.neures.2011.02.002

Nepomnaschy P. A., Welch K. B., McConnell D. S., Low B. S., Strassmann B. I., England B. G. (2006): Cortisol levels and very early pregnancy loss in humans. Proc Natl. Acad. Sci. U.S.A. 103, 3938-3942 http://dx.doi.org/10.1073/pnas.0511183103

Paré W. P., Glavin G. B. (1986): Restraint stress in biomedical research: a review. Neurosci. Biobehav. Rev. 10, 339-370 http://dx.doi.org/10.1016/0149-7634(86)90017-5

Rondó P. H. (2007): Maternal stress / distress and low birth weight, preterm birth and intrauterine growth restriction - a review. Current Women's Health Reviews 3, 13-29 http://dx.doi.org/10.2174/157340407779941886

Ruiz R. J., Fullerton J., Dudley D. J. (2003): The interrelationship of maternal stress, endocrine factors and inflammation on gestational length. Obstet. Gynecol. Surv. 58, 415-428 http://dx.doi.org/10.1097/01.OGX.0000071160.26072.DE

Sasagawa I., Yazawa H., Suzuki Y., Nakada T. (2001): Stress and testicular germ cell apoptosis. Arch. Androl. 47, 211-216 http://dx.doi.org/10.1080/014850101753145924

Sastry K. S., Karpova Y., Prokopovich S., Smith A. J., Essau B., Gersappe A., Carson J. P., Weber M. J., Register T. C., Chen Y. Q. et al. (2007): Epinephrine protects cancer cells from apoptosis via activation of cAMP-dependent protein kinase and BAD phosphorylation. J. Biol. Chem. 282, 14094-14100
http://dx.doi.org/10.1074/jbc.M611370200

Siemieniuch M. J., Majewska M., Takahashi M., Sakatani M., Lukasik K., Okuda K., Skarżyński D. J. (2010): Are glucocorticoids auto- and/or paracrine factors in early bovine embryo development and implantation? Reprod. Biol. 10, $249-256$ http://dx.doi.org/10.1016/S1642-431X(12)60045-X

Tetsuka M., Milne M., Simpson G. E., Hillier S. G. (1999): Expression of 11beta-hydroxysteroid dehydrogenase, glucocorticoid receptor, and mineralocorticoid receptor genes in rat ovary. Biol. Reprod. 60, 330-335 http://dx.doi.org/10.1095/biolreprod60.2.330

Thaete L. G., Nesbitt M. N., Malkinson A. M. (1990): Genetic analysis of the distribution of corticosterone-containing cells in mouse adrenal cortex. Proc. Soc. Exp. Biol. Med. 194, 97-102

Van der Auwera I., D’Hooghe T. (2001): Superovulation of female mice delays embryonic and fetal development. Hum. Reprod. 16, 1237-1243

http://dx.doi.org/10.1093/humrep/16.6.1237

Van Merris V., Van Wemmel K., Cortvrindt R. (2007): In vitro effects of dexamethasone on mouse ovarian function and pre-implantation embryo development. Reprod. Toxicol. 23, 32-41 http://dx.doi.org/10.1016/j.reprotox.2006.08.008

Wiebold J. L., Stanfield P. H., Becker W. C., Hillers J. K. (1986): The effect of restraint stress in early pregnancy in mice. J. Reprod. Fertil. 78, 185-192 http://dx.doi.org/10.1530/jrf.0.0780185

Wilcox A. J., Baird D. D., Weinberg C. R. (1999): Time of implantation of the conceptus and loss of pregnancy. N. Engl. J. Med. 340, 1796-1799 http://dx.doi.org/10.1056/NEJM199906103402304

Zhang S. Y., Wang J. Z., Li J. J., Wei D. L., Sui H. S., Zhang Z. H., Zhou P., Tan J. H. (2011): Maternal restraint stress diminishes the developmental potential of oocytes. Biol. Reprod. 84, 672-681 http://dx.doi.org/10.1095/biolreprod.110.087890

Received: May 23, 2012

Final version accepted: June 19, 2012 